\title{
Concentrations of Natural Radionuclides (40K, 226Ra, 232Th) at the Potash Salts Deposit
}

\author{
Elena Menshikova ${ }^{1}$, Roman Perevoshchikov, ${ }^{1}$ Pavel Belkin ${ }^{1 *}$, Sergey Blinov ${ }^{1}$ \\ 1 Department of Geology, Perm State University, Bukireva St. 15, 614990 Perm, Russia; \\ * Corresponding author's email: pashabelkin@mail.ru
}

\begin{abstract}
Specific activity of natural radionuclides $226 \mathrm{Ra}, 232 \mathrm{Th}$ and $40 \mathrm{~K}$ was measured by gamma spectrometry in samples of soil and bottom sediments of rivers on the territory of potassium salt deposit development in order to collect information on radionuclide distribution. According to the results of examinations, the range of 226Ra, $232 \mathrm{Th}$ and $40 \mathrm{~K}$ activity values in soils and bottom sediments of the territory of influence was $<2.17-19.7 \mathrm{~Bq} / \mathrm{kg}$, $<2.5-20.5 \mathrm{~Bq} / \mathrm{kg}, 123-500 \mathrm{~Bq} / \mathrm{kg}$. Migration of the studied radionuclides is limited to $2 \mathrm{~km}$ zone. The results obtained provide useful information on the levels of naturally occurring radionuclides in the zone of influence of mining objects and are of interest for a comparative evaluation of the impact of salt mining on the radiation environment of the territory.
\end{abstract}

Keywords: soils; bottom sediments; radium; thorium; potassium; $\gamma$-spectrometer; Verkhnekamskoe potash salt deposit.

\section{INTRODUCTION}

The natural radiation background of the territory is conditioned by cosmic radiation as well as by the presence of radioactive elements in the Earth's crust, water bodies and atmosphere. Among the radioactive isotopes of natural origin the most widespread and important from the ecological point of view are $238 \mathrm{U}, 232 \mathrm{Th}$, 226Ra and 40K [Paschoa et al., 2010]. The last decades of civilization development have led to radical changes in ecological conditions, in particular, to intensive radioactive contamination of the main components of the natural environment (soils, natural waters, rocks, bottom sediments) [Mirzoyeva et al., 2015]. The radiation background of any territory consists of a natural background and radioactive contamination caused by anthropogenic impact. Often high levels of radiation background are associated with natural radioactivity of rocks, as well as with geochemical features of behavior of radionuclides themselves. Therefore, when characterizing the radioecological state of the territory it is necessary to assess not only anthropogenic impact, but also the natural component and compare the data obtained with the regional background [Markelov, 2008].

Gamma spectrometric measurements of the activity of natural radionuclides in various objects of the environment are now actively used to assess the ecological state of territories. Such studies are actively conducted for soils, bottom sediments and beach sands [Abusini et al., 2008; Caridi et al., 2016; Singh et al., 2005; Yang et al., 2005; Monged et al., 2020; Dragović et al., 2012; Forkapic et al., 2017; Tahir et al., 2005; Guseva et al., 2019; Alam et al., 1999], various wastes [Beretka et al., 1985; El Afifi et al., 2009], especially for coal industry [Menshikova et al., 2019; Kozlowska et al., 2012; Sidorova et al., 2015], food salt [Caridi et al., 2019; Tahir et al., 2008; El-Bahi et al., 2003; Hançerlioğullari et al., 2020]

In the process of migration, natural radionuclides enter water bodies, accumulate in soils, grounds and bottom sediments; their high concentrations can pose danger to humans. Possible 
sources of contamination of environmental objects with natural radionuclides are natural formations - rocks with increased content of natural radionuclides [Joshua et al., 2009; Khater et al., 2013; Srinivasa et al., 2019] and industrial enterprises producing and enriching certain types of minerals (coal, oil, gas, phosphates, clay, metalliferous and non-metallic ores) [Extent ..., 2003; Guerrero et al., 2020]. The attention of researchers to the radiation situation in salt deposits is associated with the promising development of speleotherapy [Calin et al., 2012]. In particular, the use of materials based on natural potassium salt for interior decoration is a known tool to create a therapeutic effect due to air ionization [Chernyi, 2019].

The study area is one of the most developed areas of the Verkhnekamskoye potash salt deposit (Ural region, Russia). Underground mining of sylvinite (raw material for the production of potash fertilizers), carnallite (production of artificial carnallite for the magnesium industry) and brines (raw material for the production of soda) is conducted here. The geological reserves of the deposit are huge and are estimated at 96.4 billion tons for carnallite rock, 113.2 billion tons for sylvinite and 4.650 billion tons for rock salt.

The purpose of the research is to estimate the activity of natural radionuclides $226 \mathrm{Ra}, 232 \mathrm{Th}$ and $40 \mathrm{~K}$ in soils and bottom sediments within the territory of potassium salt deposit development, their spatial distribution and possible anthropogenic sources. In the investigated group of natural radionuclides, $40 \mathrm{~K}$ is of the greatest interest for the territory under consideration. Natural potassium is a mixture of three isotopes $39 \mathrm{~K}, 40 \mathrm{~K}, 41 \mathrm{~K}$, while only $40 \mathrm{~K}$ is radioactive. It is a natural radionuclide of non-serial origin that is present everywhere on the Earth. The results presented in the paper provide useful information on the content of natural radionuclides in the influence zone of mining objects and are of interest for comparative evaluation of the impact of salt mining on the formation of radiation situation of territories.

\section{METHODS}

Soil, bottom sediments and core samples were taken from an exploration well within the study area of the potassium deposit. Soil sampling points were relatively evenly dispersed throughout the territory adjacent to the mining operation. A total of 44 soil samples were taken by the dug-in method from the top soil layer (0-0.4 m interval). Bottom sediments (6 samples of fine-grained fraction) were taken from watercourses within the territory adjacent to the enterprise.

Radiation examination of the core was carried out on the exploration well in the depth interval of 3.5-349.0 m. Samples were taken from the minable seam and characteristic lithological types of rocks of the overlying strata. A total of 15 core samples were examined. To compare the results obtained from the core samples, the crushed rock in the underground space of the mine was examined. A total of 4 such samples were examined.

Specific activity of natural radionuclides (40K, 226Ra, 232Th) was studied for all samples under laboratory conditions. Gamma-spectrometric measurements of samples were done on scintillation gamma-spectrometer MKS-01A "Multirad" (Russia). Gamma-spectra were processed using the programs included in the Progress package. Errors of specific activity measurements were $\pm(20-30) \%$ of the measured value.

For the energy calibration of the spectrometer, a reference source based on 137Cs and 40K was used. The source is a 1-liter Marinelli vessel filled with $\mathrm{KCl}$, closed with a lid, in the base of which there is a cylindrical recess, where the 137 Cs source is fixed (a disc $29 \mathrm{~mm}$ in diameter, in the center of which there is an active spot, sealed with two polyamide films $50 \mu \mathrm{m}$ thick each). The source activity is $1500 \mathrm{~Bq}$, and the error (at 0.95 confidence probability) is $20 \%$. The spectrum from the gamma spectrometer's calibration source shows maximums of $137 \mathrm{Cs}$ (energy $662 \mathrm{keV}$ ) and 40K (energy $1461 \mathrm{keV}$ ) total absorption peaks, count rate in a certain energy range (usually $620-700 \mathrm{keV}$ ). In order to control own noises of gamma-spectrometric path and take into account the impact of external gamma radiation on the hardware radiation spectrum of the investigated sample, after calibration the background measurement was made (during $1800 \mathrm{sec}$ ). In the investigated samples of soil and bottom sediments their organic part was removed by calcination before measurement, the samples were mixed and placed in a Marinelli vessel up to the mark of $1 \mathrm{~L}$.

Rationing of exposure to natural radionuclides in accordance with the requirements of 
radiation safety standards (Radiation Safety Standards, Russia) was carried out according to the calculated value of specific effective activity $\mathrm{A}_{\mathrm{eff}}$, which characterizes the total specific activity of natural radionuclides in the studied material, determined taking into account their biological impact on the human body $(\mathrm{Bq} / \mathrm{kg})$. The formula for its calculation is as follows:

$$
\mathrm{A}_{\mathrm{eff}}=\mathrm{A}_{\mathrm{Ra}}+1,31 \mathrm{~A}_{\mathrm{Th}}+0,085 \mathrm{~A}_{\mathrm{K}} \text {, }
$$

where: $A_{R a}$ and $A_{T h}$ are the specific activities of $226 \mathrm{Ra}$ and $232 \mathrm{Th}(\mathrm{Bq} / \mathrm{kg})$, which are in equilibrium with the remaining members of the uranium and thorium series, $A_{K}$ is the specific activity of $40 \mathrm{~K}(\mathrm{~Bq} / \mathrm{kg})$.

\section{RESULTS AND DISCUSSION}

Soil cover, being at the intersection of migration ways of chemical elements, including radioactive elements, is the main component of the natural environment, carrying the cumulative effect of long-term anthropogenic impact [Grebenshchikova et al., 2017]. In the upper layer of soils and grounds (up to $5 \mathrm{~cm}$ ), $95-98 \%$ of anthropogenic activity is concentrated. The natural activity changes insignificantly with depth, which is why the radiation characteristics of this particular layer are the main in the analysis of soils and grounds.

According to the results of examinations of soils and bottom sediments, the maximum values of specific effective activity of the studied natural radionuclides (value range $62-88 \mathrm{~Bq} / \mathrm{kg}$ ) are observed in the soils of the sites in the immediate vicinity of the operating salt mine administration and to the north-east of it (Table 1, Table 2, Fig. 1). The obtained outlines of specific effective activity distribution of the investigated natural radionuclides correspond to the outlines of $40 \mathrm{~K}$ activity distribution (Fig. 2). The formed zone of higher concentrations of natural radionuclides is conditioned by the wind regime of the territory of research, where a high frequency of southern direction winds is observed during a year. Taking into account the prevailing wind direction, there is a significant removal of substances with atmospheric flows in the northern and northeastern directions.

Developed potassium ores are the source of $40 \mathrm{~K}$ entry into the environment. Radiation study of the exploration well core (Table 3 ) demonstrates high values of $40 \mathrm{~K}$ activity in productive potassium formations which is caused by their mineral composition. For the considered deposit the highest values are typical for mottled sylvinites (up to $4967 \mathrm{~Bq} / \mathrm{kg}$ ), which is significantly higher than the $40 \mathrm{~K}$ activity for generalized data on sedimentary rocks and continental crust. All examined samples of potassium salts do not exceed the permissible value of $740 \mathrm{~Bq} / \mathrm{kg}$ by the rated specific effective activity (Radiation Safety Standards, Russia).

The mine site administration monitors atmospheric air at a number of locations on the border of the sanitary protection zone of industrial facilities on a monthly basis. Potassium chloride and sodium chloride are defined among other constituents. The control results show that the maximum permissible concentrations are not exceeded $\left(0.3 \mathrm{mg} / \mathrm{m}^{3}\right.$ for $\mathrm{KCl}$, $0.5 \mathrm{mg} / \mathrm{m}^{3}$ for $\mathrm{NaCl}$ ). Taking into account the volume of emissions into the atmospheric air, the main entry of potassium chloride and sodium chloride is connected with the emissions of the drying department of the fertilizer production plant. According to the results obtained, migration of the studied radionuclides is limited to the zone of $2 \mathrm{~km}$. Only insignificant part of the investigated samples $(8 \%)$ exceeds the worldwide average activity of $40 \mathrm{~K}$ for soils. In bottom sediments the average activity of $40 \mathrm{~K}$ does not exceed the values for other territories with anthropogenic impact. The situation is different for the content of 226Ra and 232Th. Even their maximum activities in the investigated soil samples are essentially lower than the worldwide average values.

The quantitative state of radioactive equilibrium in various objects of the environment is characterized by the coefficient of radioactive equilibrium, which is the ratio of the activity of a given radionuclide to the activity of the radionuclide that originated or preceded it in the radioactive series [Vertman et al., 2002]. If the radioactive equilibrium is not disturbed, the ratio will be 1 . Thus, the ratio of activity values $232 \mathrm{Th} / 226 \mathrm{Ra}<1$ in soils can serve as an indicator of anthropogenic impact. The results of the conducted assessment for soils of the study area showed several zones with disturbed ratio of these natural radionuclides (Table 4, Fig. 3). The configuration of the isolated zones of imbalance indicates the absence of their connection with the activities of the mine of potassium salts. 
Table 1. Specific activity of natural radionuclides in soils

Activity concentrations of 226Ra, 232Th and $40 \mathrm{~K}(\mathrm{~Bq} / \mathrm{kg})$ in soul samples

\begin{tabular}{|c|c|c|c|c|}
\hline \multirow{2}{*}{ Sample code } & \multicolumn{4}{|c|}{ Activity concentration $(\mathrm{Bq} / \mathrm{kg})$} \\
\hline & $40 \mathrm{~K}$ & 226Ra & 232Th & Aeff \\
\hline S1 & $143.30 \pm 26.00$ & $9.10 \pm 3.00$ & $<2,82$ & $22.36 \pm 4.53$ \\
\hline $\mathrm{S} 2$ & $364.50 \pm 90.40$ & $9.70 \pm 3.80$ & $8.62 \pm 3.73$ & $53.70 \pm 10.20$ \\
\hline S3 & $301.70 \pm 79.40$ & $13.47 \pm 4.21$ & $10.6 \pm 3.90$ & $54.40 \pm 9.70$ \\
\hline S4 & $157.20 \pm 27.00$ & $3.40 \pm 2.00$ & $4.48 \pm 2.00$ & $22.63 \pm 3.99$ \\
\hline S5 & $281.80 \pm 78.10$ & $6.61 \pm 3.52$ & $6.52 \pm 3.55$ & $40.40 \pm 9.10$ \\
\hline S6 & $166.10 \pm 30.00$ & $6.76 \pm 3.00$ & $4.08 \pm 2.00$ & $26.22 \pm 4.70$ \\
\hline S7 & $173.40 \pm 28.00$ & $9.72 \pm 3.00$ & $3.92 \pm 2.00$ & $29.59 \pm 4.61$ \\
\hline S8 & $154.00 \pm 27.00$ & $6.70 \pm 3.00$ & $4.78 \pm 2.00$ & $26.05 \pm 4.57$ \\
\hline s9 & $151.40 \pm 27.00$ & $6.09 \pm 3.00$ & $4.59 \pm 2.00$ & $24.97 \pm 4.57$ \\
\hline S10 & $186.50 \pm 32.00$ & $8,99 \pm 3.00$ & $5,75 \pm 2.00$ & $32,37 \pm 4.79$ \\
\hline S11 & $215.00 \pm 35.00$ & $7.25 \pm 3.00$ & $6.33 \pm 2.00$ & $33.81 \pm 4.93$ \\
\hline S12 & $123.60 \pm 23.00$ & $8.26 \pm 3.00$ & $<3,8$ & $21.12 \pm 4.41$ \\
\hline $\mathrm{S} 13$ & $155.80 \pm 27.00$ & $6.17 \pm 3.00$ & $3.82 \pm 2.00$ & $24.42 \pm 4.57$ \\
\hline S14 & $129.00 \pm 24.00$ & $6.54 \pm 2.00$ & $<3.82$ & $19.89 \pm 3.85$ \\
\hline S15 & $489.00 \pm 125.00$ & $19.70 \pm 6.30$ & $17.70 \pm 6.2$ & $84.40 \pm 14.6$ \\
\hline S16 & $407.00 \pm 114.00$ & $19.10 \pm 6.70$ & $20.50 \pm 7.20$ & $80.60 \pm 15.00$ \\
\hline S17 & $308.00 \pm 127.00$ & $18.20 \pm 8.00$ & $9.30 \pm 7.60$ & $62.60 \pm 16.50$ \\
\hline S18 & $432.00 \pm 51.00$ & $15.80 \pm 9.20$ & $12.20 \pm 9.50$ & $68.50 \pm 19.90$ \\
\hline S19 & $500.00 \pm 127.00$ & $18.90 \pm 6.30$ & $20.30 \pm 6.70$ & $88.00 \pm 15.1$ \\
\hline S20 & $406.00 \pm 92.00$ & $15.60 \pm 4.20$ & $14.70 \pm 4.17$ & $69.30 \pm 10.35$ \\
\hline S21 & $410.00 \pm 102.00$ & $16.10 \pm 5.00$ & $10.10 \pm 4.40$ & $64.20 \pm 11.40$ \\
\hline $\mathrm{S} 22$ & $385.00 \pm 109$ & $9.30 \pm 5.50$ & $12.90 \pm 6.20$ & $58.90 \pm 13.30$ \\
\hline S23 & $169.20 \pm 28.00$ & $6.37 \pm 2.00$ & $5.29 \pm 2.00$ & $27.68 \pm 4.03$ \\
\hline S24 & $151.20 \pm 26.00$ & $5.04 \pm 2.00$ & $5.66 \pm 2.00$ & $25.31 \pm 3.94$ \\
\hline S25 & $195.10 \pm 31.00$ & $5.80 \pm 2.00$ & $7.68 \pm 2.00$ & $32.45 \pm 4.18$ \\
\hline S26 & $163.50 \pm 28.00$ & $9.17 \pm 3.00$ & $2.89 \pm 2.00$ & $26.85 \pm 4.61$ \\
\hline S27 & $195.70 \pm 32.00$ & $7.19 \pm 3.00$ & $7.66 \pm 2.00$ & $33.86 \pm 4.79$ \\
\hline S28 & $195.50 \pm 35.50$ & $9.50 \pm 3.00$ & $6.42 \pm 3,00$ & $34.53 \pm 5,73$ \\
\hline $\mathrm{S} 29$ & $193.20 \pm 34.00$ & $8.08 \pm 3.00$ & $9.06 \pm 3.00$ & $36.37 \pm 5.69$ \\
\hline $\mathrm{S} 30$ & $169.3 \pm 31.00$ & $<2.17$ & $2.59 \pm 2.00$ & $17.96 \pm 4.18$ \\
\hline S31 & $158.8 \pm 55.00$ & $7.09 \pm 3.27$ & $4.53 \pm 2.98$ & $27.30 \pm 7.10$ \\
\hline S32 & $123.20 \pm 26.00$ & $5.79 \pm 3.00$ & $<3.00$ & $16.26 \pm 4.53$ \\
\hline S33 & $180.90 \pm 33.00$ & $4.53 \pm 3.00$ & $8.08 \pm 3.00$ & $30.49 \pm 5.65$ \\
\hline S34 & $141.2 \pm 28.00$ & $4.59 \pm 3.00$ & $<2.49$ & $17.24 \pm 4.61$ \\
\hline S35 & $144.90 \pm 27.00$ & $<3.00$ & $<3.06$ & $14.60 \pm 3.98$ \\
\hline Middle & 234.91 & 9.14 & 7.43 & 38.55 \\
\hline Max & $500.00 \pm 127.00$ & $19.70 \pm 6.30$ & $20.50 \pm 6.70$ & $88.00 \pm 15.1$ \\
\hline Min & $123.20 \pm 26.00$ & $<2.17$ & $<2.49$ & $14.60 \pm 3.98$ \\
\hline $\begin{array}{l}\text { Summary world data } \\
\text { [UNSCEAR ..., 2000] }\end{array}$ & 420 & 32 & 45 & - \\
\hline $\begin{array}{c}\text { Average } 2019 \text { values for Moscow soils } \\
\text { [Radiation situation ..., 2020] }\end{array}$ & 442 & 19 & 24 & 90 \\
\hline
\end{tabular}


Table 2. Specific activity of natural radionuclides in samples of bottom sediments Activity concentrations of 226Ra, 232Th and 40K (Bq/ $/ \mathrm{kg})$ in samples of bottom sediments

\begin{tabular}{|l|c|c|c|c|}
\hline \multirow{2}{*}{ Sample code } & \multicolumn{4}{|c|}{ Activity concentration (Bq/kg) } \\
\cline { 2 - 5 } & $40 K$ & $226 \mathrm{Ra}$ & 232Th & Aeff \\
\hline D1 & $313.00 \pm 86.00$ & $7.90 \pm 4.00$ & $14.30 \pm 4.90$ & $53.30 \pm 10.4$ \\
\hline D2 & $314.00 \pm 87.00$ & $12.60 \pm 4.60$ & $16.80 \pm 5.30$ & $61.30 \pm 11.00$ \\
\hline D3 & $234.30 \pm 58.00$ & $6.61 \pm 2.63$ & $7.85 \pm 2.66$ & $37.90 \pm 6.80$ \\
\hline D4 & $144.10 \pm 26.00$ & $9.20 \pm 3.00$ & $6.16 \pm 2.00$ & $29.52 \pm 4.53$ \\
\hline D5 & $283.40 \pm 70.90$ & $6.42 \pm 2.97$ & $8.66 \pm 3.19$ & $43.20 \pm 8 / 20$ \\
\hline D6 & $131.20 \pm 22.00$ & $2.39 \pm 2.00$ & $6.08 \pm 2.00$ & $21.51 \pm 3.77$ \\
\hline Middle & 236.67 & 7.52 & 9.98 & 41.12 \\
\hline $\begin{array}{l}\text { Summarized data on the } \\
\text { content in the sediments of } \\
\text { Lake Karun [Rafat, 2015] }\end{array}$ & $410-1426$ & $6,2-22,4$ & $5,2-26,6$ & - \\
\hline $\begin{array}{l}\text { Average 2019 values for the } \\
\text { bottom sediments of Moscow } \\
\text { [Radiation situation ..., 2020] }\end{array}$ & 279 & 15 & 20 & 66 \\
\hline $\begin{array}{l}\text { Summary data on Sedimentary } \\
\text { rocks [Paschoa et al., 2010] }\end{array}$ & $<300-900$ & - & $<8-50$ & - \\
\hline
\end{tabular}

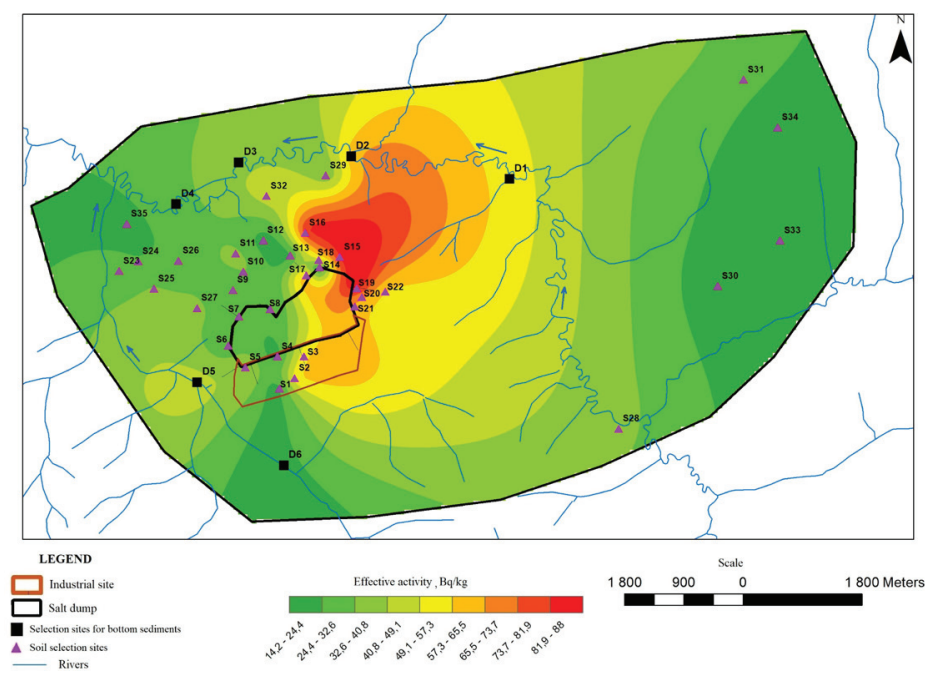

Figure 1. Specific effective activity of natural radionuclides in soils and bottom sediments in the study area



Figure 2. Specific activity of $40 \mathrm{~K}$ in soils and bottom sediments in the study area 
Table 3. Specific activity of natural radionuclides in rocks of exploration well and crushed ore Activity concentrations of $226 \mathrm{Ra}, 232 \mathrm{Th}$, and $40 \mathrm{~K}(\mathrm{~Bq} / \mathrm{kg})$ in rocks from an exploration well and shredded ore

\begin{tabular}{|c|c|c|c|c|c|}
\hline \multirow{2}{*}{$\begin{array}{l}\text { Sample } \\
\text { code }\end{array}$} & \multirow{2}{*}{$\begin{array}{c}\text { Rocks } \\
\text { (sampling interval, } \mathrm{m} \text { ) }\end{array}$} & \multicolumn{4}{|c|}{ Activity concentration $(\mathrm{Bq} / \mathrm{kg})$} \\
\hline & & ${ }^{40} \mathrm{~K}$ & ${ }^{232} \mathrm{Th}$ & ${ }^{226} \mathrm{Ra}$ & Aeff \\
\hline $\mathrm{SI}-1$ & Loam $(3,5-4,0)$ & $333 \pm 55$ & $15,3 \pm 5$ & $17,3 \pm 3$ & $67,16 \pm 14,45$ \\
\hline $\mathrm{SI}-2$ & Mergel $(13,0-13,5)$ & $177 \pm 37$ & $7,5 \pm 4$ & $4,9 \pm 3$ & $30,58 \pm 11,53$ \\
\hline SI-3 & Clayeymarl $(26,2-26,4)$ & $382 \pm 60$ & $12,9 \pm 5$ & $7,3 \pm 3$ & $58,45 \pm 14,90$ \\
\hline $\mathrm{SI}-4$ & Clayeymergel $(29,4-29,5)$ & $346 \pm 56$ & $17,3 \pm 5$ & $7 \pm 3$ & $60,63 \pm 14,54$ \\
\hline $\mathrm{SI}-5$ & clayeymergel $(151,9-152,1)$ & $359 \pm 57$ & $20,9 \pm 5$ & $4,6 \pm 3$ & $64,08 \pm 14,63$ \\
\hline SI-6 & Gypsummergel $(173,4-173,8)$ & $927 \pm 195$ & $22,2 \pm 6,26$ & $6,26 \pm 4,89$ & $118,55 \pm 30,58$ \\
\hline $\mathrm{SI}-7$ & Rocksalt (197.0-197.3) & $3 \pm 0$ & $3,2 \pm 3$ & $3 \pm 0$ & $7,43 \pm 3,9$ \\
\hline SI-8 & Carnallite (226.7-227.0) & $2896 \pm 330$ & $19,8 \pm 5$ & $3 \pm 0$ & $289,38 \pm 36,2$ \\
\hline SI-9 & Carnallite (245.5-245.9) & $3031 \pm 340$ & $17,8 \pm 5$ & $3 \pm 0$ & $298,93 \pm 37,1$ \\
\hline $\mathrm{SI}-10$ & Carnallite (272.8-273.2) & $2824 \pm 320$ & $16,7 \pm 5$ & $3 \pm 0$ & $278,87 \pm 35,3$ \\
\hline $\mathrm{SI}-11$ & Mottled sylvinite $(282,6-283,0)$ & $4967 \pm 540$ & $38,3 \pm 8$ & $3 \pm 0$ & $499,82 \pm 59,00$ \\
\hline $\mathrm{SI}-12$ & Striated sylvinite $(284,9-285,4)$ & $3393 \pm 380$ & $41 \pm 8$ & $3 \pm 0$ & $361,67 \pm 44,60$ \\
\hline $\mathrm{SI}-13$ & Red sylvinite $(296,5-297,1)$ & $2055 \pm 240$ & $16,4 \pm 5$ & $3 \pm 0$ & $209,27 \pm 28,10$ \\
\hline $\mathrm{SI}-14$ & Striated sylvinite $(304,0-304,55)$ & $4542 \pm 470$ & $24,9 \pm 6$ & $3 \pm 0$ & $418,05 \pm 50,10$ \\
\hline $\mathrm{SI}-15$ & Rocksalt (348.3-348.9) & $3 \pm 0$ & $3 \pm 0$ & $3 \pm 0$ & $7,17 \pm 0,00$ \\
\hline \multicolumn{6}{|c|}{ Crushed ore } \\
\hline GS-1 & Ground sylvinite & $4510 \pm 730$ & $<8$ & $14,5 \pm 4,2$ & $398 \pm 66$ \\
\hline GS-2 & Ground sylvinite & $4612 \pm 742$ & $<8$ & $<8$ & $418 \pm 67$ \\
\hline GG-1 & Halite waste & $283 \pm 70$ & $<8$ & $<8$ & $24 \pm 6$ \\
\hline GG-2 & Halite waste & $297 \pm 66$ & $<8$ & $<8$ & $27 \pm 7$ \\
\hline \multicolumn{2}{|c|}{$\begin{array}{c}\text { Summary of salt data the KhewraMines, Pakistan } \\
\text { [Baloch et al., 2012] }\end{array}$} & $36 \pm 20$ & - & - & - \\
\hline \multicolumn{2}{|c|}{$\begin{array}{c}\text { Summary data on rocks [Paschoa et al., 2010] } \\
\text { Sedimentary rocks } \\
\text { Continental crust }\end{array}$} & $\begin{array}{l}<300-900 \\
850\end{array}$ & $\begin{array}{c}<8-50 \\
44\end{array}$ & - & - \\
\hline
\end{tabular}

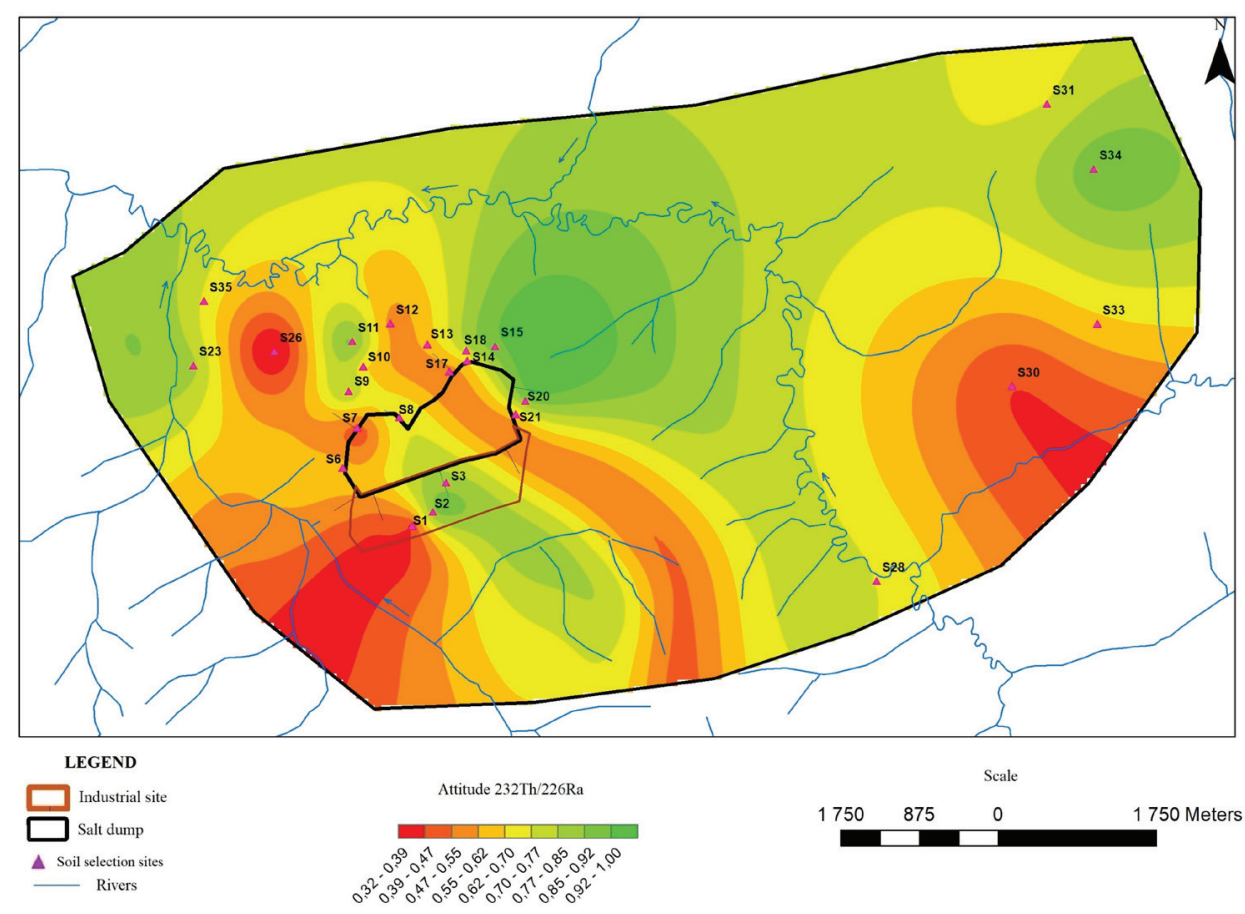

Figure 3. Ratio of specific activity of $232 \mathrm{Th}$ and $226 \mathrm{Ra}$ in soil cover 
Table 4. Significant ratios of the value of specific activity $232 \mathrm{Th}$ and $226 \mathrm{Ra}$ in soil cover

\begin{tabular}{|c|c|c|c|}
\hline \multirow{2}{*}{ Sample code } & \multicolumn{2}{|c|}{$\begin{array}{l}\text { Activity concentration } \\
(\mathrm{Bq} / \mathrm{kg})\end{array}$} & \multirow{2}{*}{$232 \mathrm{Th} / 226 \mathrm{Ra}$} \\
\hline & 232Th & 226Ra & \\
\hline S1 & 2,8 & 9,1 & 0,3 \\
\hline S2 & 8,6 & 9,7 & 0,9 \\
\hline S3 & 10,6 & 13,5 & 0,8 \\
\hline S6 & 4,1 & 6,8 & 0,6 \\
\hline S7 & 3,9 & 9,7 & 0,4 \\
\hline S8 & 4,8 & 6,7 & 0,7 \\
\hline S9 & 4,6 & 6,1 & 0,8 \\
\hline $\mathrm{S} 10$ & 5,8 & 9 & 0,6 \\
\hline $\mathrm{S} 11$ & 6,3 & 7,3 & 0,9 \\
\hline S12 & 3,8 & 8,3 & 0,5 \\
\hline $\mathrm{S} 13$ & 3,8 & 6,2 & 0,6 \\
\hline S14 & 3,8 & 6,5 & 0,6 \\
\hline S15 & 17,7 & 19,7 & 0,9 \\
\hline S17 & 9,3 & 18,2 & 0,5 \\
\hline S18 & 12,2 & 15,8 & 0,8 \\
\hline S20 & 14,7 & 15,6 & 0,9 \\
\hline $\mathrm{S} 21$ & 10,1 & 16,1 & 0,6 \\
\hline S23 & 5,3 & 6,4 & 0,8 \\
\hline S26 & 2,9 & 9,2 & 0,3 \\
\hline S28 & 6,4 & 9,5 & 0,7 \\
\hline $\mathrm{S} 30$ & 3,2 & 7,2 & 0,4 \\
\hline S31 & 5,4 & 7,3 & 0,7 \\
\hline S33 & 4,4 & 7,7 & 0,6 \\
\hline S34 & 3,0 & 3,8 & 0,9 \\
\hline S35 & 3,4 & 4,7 & 0,7 \\
\hline $\begin{array}{l}\text { Range of indicators } \\
\text { for the soils of the } \\
\text { study area }\end{array}$ & $2,8-17,7$ & $3,8-19,7$ & $0,3-0,9$ \\
\hline $\begin{array}{l}\text { Significance of } \\
\text { indicators in soil- } \\
\text { forming rocks }\end{array}$ & $15,3 \pm 5$ & $17,3 \pm 3$ & 0,88 \\
\hline
\end{tabular}

\section{CONCLUSIONS}

Monitoring of changes in radiation background and radionuclide activity is currently an important task in order to assess the radiation situation in industrial and urbanized areas. In spite of the high activity of $40 \mathrm{~K}$ in the developed potassium ores, the value of this index for the majority of investigated soil samples at the Verkhnekamskoye salt deposit does not exceed worldwide average values, for samples of bottom sediments - values of other territories with anthropogenic influence. Migration of the investigated radionuclides is limited to the zone of $2 \mathrm{~km}$. Even the maximum activities of 226Ra and 232Th in the investigated soil samples are significantly lower than the worldwide average values. All this allows us to conclude that the underground development of the deposit has no effect on the radiation situation of the territory under study. The results of the studies can be used in solving the problems of radiation monitoring of mining enterprises and environmental assessment of territories, taking into account the radiation loads.

\section{Acknowledgements}

The publication has been prepared as part of the implementation of the Program of activities of the world-class scientific and educational center "Rational Subsoil Use" for 2019-2024 with the financial support of the Ministry of Education and Science of the Russian Federation.

\section{REFERENCES}

1. Abusini M., Al-Ayasreh K., Al-jundi J. 2008. Determination of uranium, thorium and potassium activity concentrations in soil cores in Araba valley, Jordan. Radiation Protection Dosimetry, 128(2), 213-216. DOI: 10.1093/rpd/ncm327.

2. Alam M.N., Chowdhury M.I., Kamal M., Ghose S., Islam M.N., Mustafa, M.N., Miah M.M.H., Ansary M.M. 1999. The 226Ra, 232Th and 40K activities in beach sand minerals and beach soils of Cox's Bazar, Bangladesh. Journal of Environmental Radioactivity, 46(2), 243-250. DOI: 10.1016/ S0265-931X(98)00143-X.

3. Baloch M.A., Qureshi A.A., Waheed A. 2012. A study on natural radioactivity in khewra salt mines, Pakistan. Journal of Radiation Research, 53(3), 411-421. DOI: 10.1269/jrr.11162.

4. Beretka J., Mathew P.J. 1985. Natural radioactivity of australian building materials, industrial wastes and by-products. Health Physics, 48(1), 87-95. DOI: 10.1097/00004032-198501000-00007.

5. Calin M.R., Calin M.A., Simionca G., Mera, O. 2012. Indoor radon levels and natural radioactivity in Turda salt mine, Romania. Journal of Radioanalytical and Nuclear Chemistry, 292 (1), 193-201. DOI: $10.1007 / \mathrm{s} 10967-011-1394-2$.

6. Caridi F., D’Agostino M., Marguccio S., Belvedere A., Belmusto G., Marcianò G., Sabatino G., Mottese A. 2016. Radioactivity, granulometric and elemental analysis of river sediments samples from the coast of Calabria, south of Italy. European Physical Journal Plus, 131 (5), 136. DOI: 10.1140/epjp/i2016-16136-1.

7. Caridi F., Messina M., Belvedere A., D’Agostino M., Marguccio S., Settineri L., Belmusto G. 2019. 
Food salt characterization in terms of radioactivity and metals contamination. Applied Sciences, 9(14), 2882. DOI: $10.3390 /$ app9142882.

8. Chernyi K.A. 2019. Ionization radiation parameters and their spatial variation patterns in potash salt. Gornyy zhurnal, 1, 75-80. DOI: 10.17580/ gzh.2019.01.16. (In Russ.).

9. Dragović S., Gajić B., Dragović R., JankovićMandić L., Slavković-Beškoski L., Mihailović N., Momčilović M., Ćujić M. 2012. Edaphic factors affecting the vertical distribution of radionuclides in the different soil types of Belgrade, Serbia. Journal of Environmental Monitoring, 14(1), 2012, 127137. DOI: $10.1039 / \mathrm{c} 1 \mathrm{em} 10457 \mathrm{~h}$.

10. El Afifi E.M., Hilal M.A., Attallah M.F., EL-Reefy S.A. 2009. Characterization of phosphogypsum wastes associated with phosphoric acid and fertilizers production. Journal of Environmental Radioactivity, 100(5), 407-412. DOI: 10.1016/j. jenvrad.2009.01.005

11. El-Bahi S.M. 2003. Radioactivity levels of salt for natural sediments in the northwestern desert and local markets in Egypt. Applied Radiation and Isotopes, 58(1), 143-148. DOI: 10.1016/ S0969-8043(02)00270-1.

12. Extent of environmental contamination by naturally occurring radioactive material (NORM) and technological options for mitigation. 2003. IAEA, International Atomic Energy Agency. Technical Report. IAEA. P.1-3.

13. Forkapic S., Vasin J., Bikit I., Mrdja D., Bikit K., Milić S. Correlations between soil characteristics and radioactivity content of Vojvodina soil. 2017. Journal of Environmental Radioactivity, 166(1), 104-111. DOI: 10.1016/j.jenvrad.2016.04.003.

14. Grebenshchikova V.I., Gritsko P.P., Kuznetsov P.V., Doroshkov A.A. 2017. Uranium and thorium in the soil cover of the Irkutsk-Angara industrial zone (Pribaikalye). Izvestiya Tomskogo politekhnicheskogo universiteta, 328(7), 93-104. (In Russ.)

15. Guerrero J.L., Gutiérrez-Álvarez I., Mosqueda F., Gázquez M.J., García-Tenorio R., Olías, M., Bolívar J.P. 2020. Evaluation of the radioactive pollution in the salt-marshes under a phosphogypsum stack system. Environmental Pollution, 258, 113729. DOI: 10.1016/j.envpol.2019.113729.

16. Guseva A.S., Ustinov S.A., Petrov V.A. 2019. Distribution of natural radionuclides in the soils on the territory of the New Moscow. Proceedings of higher educational establishments. Geology and Exploration, 5, 88-94. (In Russ.) DOI: 10.32454/0016-7762-2019-5-88-94. (In Russ.)

17. Hançerlioğullari A. \& Eyüboğlu K. 2020. Natural radionuclide and toxic metal contents of rock salts from mines in Central Anatolia of Turkey. International Journal of Environmental Analytical
Chemistry. DOI: 10.1080/03067319.2020.1814264.

18. Joshua E.O., Ademola J.A., Akpanowo M.A., Oyebanjo, O.A., Olorode, D.O. 2009. Natural radionuclides and hazards of rock samples collected from Southeastern Nigeria. Radiation Measurements, 44(4), 401-404. DOI: 10.1016/j. radmeas.2009.04.002

19. Khater A.E.M., Al-Mobark L.H, Aly, A.A., Al-Omran A.M. 2013. Natural radionuclides in clay deposits: Concentration and dose assessment. Radiation Protection Dosimetry, 156(3), 321-330. DOI: 10.1093/rpd/nct064.

20. Kozlowska B., Walencik A., Dorda J., Zipper W. 2012. Radioactivity of dumps in mining areas of the Upper Silesian Coal Basin in Poland. Proc. EPJ Web of Conferences 24, 05006. DOI: 10.1051/ epjconf/20122405006.

21. Markelov D.A. 2008. Radioecological condition of territories (assessment, diagnosis, forecasting). Energiya, Moscow. (In Russ.)

22. Menshikova E.A., Blinov S.M., Belyshev D.A., Perevoshchikov R.D. 2019. Radiation studies of dumps of the Kizelovsky coal basin. Izvestiya Uralskogo gosudarstvennogo gornogo universiteta, 56(4), 81-89. DOI: 10.21440/2307-2091-2019-481-89. (In Russ.).

23. Mirzoyeva N., Gulina L., Gulin S., Plotitsina O., Stetsuk A., Arkhipova S., Korkishko N., Eremin O. 2015. Radionuclides and mercury in the salt lakes of the Crimea. Chinese Journal of Oceanology and Limnology, 33(6), 1413-1425. DOI: 10.1007/ s00343-015-4374-5.

24. Monged M.H.E, Hassan H.B., El-Sayed S.A. 2020. Spatial Distribution and Ecological Risk Assessment of Natural Radionuclides and Trace Elements in Agricultural Soil of Northeastern Nile Valley. Egypt. Water, Air, and Soil Pollution, 231(7), 338. DOI: $10.1007 / \mathrm{s} 11270-020-04678-9$.

25. Paschoa A.S., Steinhäusler F. 2010. Terrestrial, Atmospheric and Aquatic Natural Radioactivity. Radioactivity in the Environment, 17, 29-85. DOI: 10.1016/S1569-4860(09)01703-3.

26. Radiation Situation on the Territory of Russia and Neighbouring States in 2019. Ezhegodnik. 2020. Roshydromet, Obninsk.

27. Rafat M.A. 2015. Radioactivity Levels in Some Sediments and Water Samples from Qarun Lake by Low-Level Gamma Spectrometry. International Journal of Science and Research, 4(2), 619-625.

28. Sidorova G.P., Krylov D.A. 2015. Assessment of radioactive elements in coal and its combustion products. Gornyy informatsionno-analiticheskiy byulleten, 7, 369-376. (In Russ.).

29. Singh, S., Rani, A., Mahajan, R.K. 2005. 226Ra, $232 \mathrm{Th}$ and $40 \mathrm{~K}$ analysis in soil samples from 
some areas of Punjab and Himachal Pradesh, India using gamma ray spectrometry. Radiation Measurements, 39(4), 431-439. DOI: 10.1016/j. radmeas.2004.09.003.

30. Srinivasa E., Rangaswamy D.R., Sannappa J. 2019. Assessment of radiological hazards and effective dose from natural radioactivity in rock samples of Hassan district, Karnataka, India. Environmental Earth Sciences, 78(14), 431. DOI: 10.1007/s12665-019-8465-z.

31. Tahir S.N.A., Alaamer A.S. 2008. Determination of natural radioactivity in rock salt and radiation doses due to its ingestion. Journal of Radiological Protection, 28(2), 233-236. DOI: 10.1088/0952-4746/28/2/N01.
32. UNSCEAR. 2000. Sources, effects and risks of ionizing radiation. UNSCEAR, Report to the General Assembly, with annexes.

33. Vertman E.G., Karatayev V.D., Levitskiy V.M., Ergashev D.E. 2002. A study of the surface distribution of uranium isotopes over the territory of Tomsk District. Izvestiya Tomskogo politekhnicheskogo Universiteta, 305(3), 45-55. (In Russ.).

34. Yang, Y.-X., Wu X.-M., Jiang, Z.-Y., Wang W.X., Lu J.-G., Lin J., Wang L.-M., Hsia, Y.-F. 2005. Radioactivity concentrations in soils of the Xiazhuang granite area, China. Applied Radiation and Isotopes, 63(2), 255-259. DOI: 10.1016/j. apradiso.2005.02.011. 